\title{
Ethics and Cambodian worldviews on nature
}

\author{
BunRong Kouy* \\ Graduate Institute of Philosophy, National Central University, 300 Jhongda Rd., Jhong Li City, \\ Taoyuan Country, 32001, Taiwan, ROC
}

\begin{abstract}
Every person lives with some relationship to nature, and we all construct a worldview of nature through the balancing of our collective and various ethical worldviews towards nature. The Kingdom of Cambodia in South East Asia has a population of over 14 million people. The geography of the tropical country enables nature to grow vigorously, which offers a source of generally abundant food, and this has affected the worldview of Cambodians. Cambodia is said to be a land of paddies and forests, dominated by the Mekong River and the Tonle Sap lake and river. Having been dependent on nature and facing the questions of ethical development in an industrial society, it is important to understand the perceptions of the Angkorian descendants on nature. This paper describes worldviews of nature from Cambodian perspectives with examples of anthropocentrism, biocentrism, ecocentrism, and cosmocentrism.
\end{abstract}

KEY WORDS: Cambodia $\cdot$ Nature $\cdot$ Culture $\cdot$ Anthropocentrism $\cdot$ Biocentrism $\cdot$ Ecocentrism Cosmocentrism

\section{INTRODUCTION: CAMBODIAN GEOGRAPHY, HISTORY, PEOPLE, AND RELIGION}

Cambodia is a tropical country situated north of the Equator within latitudes $10^{\circ}$ and $15^{\circ} \mathrm{N}$ and longitudes $102^{\circ}$ and $108^{\circ} \mathrm{E}$. It shares a common border with Thailand in the northwest, Laos in the north, Vietnam in the southeast, and the Gulf of Siam in the south; its total area covers $181035 \mathrm{~km}^{2}$. Dangrek Mountain, located in the north, and the Cardamom Mountains in the southwest form natural boundaries that shield the country from typhoons.

Culture affects how scientific findings are interpreted and how ethical concepts are developed. The cultural framework itself is structured through religious traditions and ideologies, politics, scientific understanding, education, and people's worldviews. Different views of nature held by different cultures therefore affect their understanding of biological processes, including interpretations of effects upon them, and their moral and ethical significance.

Cambodia's history has affected its culture. Over a period of 300 years, between 900 and $1200 \mathrm{AD}$, the
Khmer Kingdom of Angkor produced one of the world's most magnificent architectural masterpieces, known as the Angkor Wat temple, on the northern shore of the Tonle Sap lake. The Angkor area stretches approximately $25 \mathrm{~km}$ east to west and $8 \mathrm{~km}$ north to south. There are 72 major temples or other buildings in the area. King Suryavarman II built the principal temple, Angkor Wat, between 1112 and $1150 \mathrm{AD}$ with the collaborative labor of elephants and humans. With walls nearly $800 \mathrm{~m}$ on each side, Angkor Wat portrays the Hindu cosmology with the central towers representing Mount Meru, home of the gods; the outer walls represent the mountains enclosing the world, and the moat signifies the oceans beyond. Angkor Thom, the capital city built after the sacking of Cham in $1177 \mathrm{AD}$, was surrounded by a $\sim 100 \mathrm{~m}$ wide moat. Construction of Angkor Thom coincided with a change from Hinduism to Buddhism. Temples were altered to display images of the Buddha, and Angkor Wat became a major Buddhist shrine.

According to the Bureau of East Asian and Pacific Affairs (2011), $90 \%$ of Cambodia's population is eth- 
nically Cambodian or Khmer. Other ethnic groups include Chinese, Vietnamese, hill tribes, Cham (Muslims), and Laotian. Theravada Buddhism is the national religion, which $95 \%$ of the population practice; Islam, animism, and Christianity are also practiced. Nevertheless, animism has remained deeply rooted since ancient times.

\section{ENVIRONMENTAL CONCEPT IN CAMBODIAN TRADITION: HUMAN NATURE}

Based on what has been left behind from the past, intertwined between Hinduism and Buddhism, Cambodia seems to be a superstitious country. In this regard, evidence of nature can be found tangibly and intangibly, ranging from daily living habits to temple construction. Over a thousand years ago, the king of Cambodia built temples across the country, integrating nature as one of the constructed elements. For instance, water, as an element of nature, is given a high value, not only because of our dependency on it to maintain physical life, but also as a spiritual cleaning substance. A prime example of this phenomenon can be found in the Kbal Spean River, north of Siem Reap province. The water flows over sculptures carved directly into the stone riverbed. These sculptures represent Brahmanic mythological scenes and comprise a particularly great number of linga-yoni pairs (male and female principles). The water is consecrated as it flows over these sacred sculptures before reaching the rice fields downstream. A similar procedure serves to consecrate the water at the Western Baray, the largest artificial reservoir constructed during the Angkorian period. In the middle of the Baray lies an artificial island, the Mebon, at the center of which is a large stone-walled well thought to have represented a hollow linga. As this linga is effectively immersed in the Baray, the water is sanctified and made fertile before irrigating the fields. This example suggests a preliminary understanding of the way in which humanity, whether the individual or the social body, has an intimate, filial relationship to nature, but a nature that has been deeply marked by the demands of culture, in the broadest sense of the word. This is what we might call 'human nature.'

Another example is the sacred layout of Cambodian monasteries. Very schematically, the monastery is organized in relation to the temple (vihear), which is its center. From the ritual point of view, it comprises 2 sacred perimeters, which are successive and concentric. The first, which delimits the temple, is defined by 8 sima (Sanskrit and Pali for 'limit' or 'boundary'), on the 8 cardinal and intercardinal points, often materially expressed by stone landmarks called 'leaves'. It separates the sacred territory of the temple from the rest of the monastery, which, though less tabooed than the first perimeter, nevertheless remains more or less ritually marked in comparison to the profane territory of the village. It is generally surrounded by an enclosure (Ang 1988).

\section{Anthropocentrism}

Anthropocentrism includes the viewpoint that regards humankind as the central or most important element of existence, especially as opposed to God or animals. The beginning of anthropocentrism probably began with the agricultural revolution around 6000 to $7000 \mathrm{BC}$. This was the time when the human population started to expand, and humans began to breed, cultivate, and harvest plants as well as raise animals. Natural habitats (e.g. grassland and forest) were replaced with farmlands and villages. In Cambodia, the first industrial revolution occurred during the reign of King Norodom Sihanouk from 1953 to 1970. However, industrial progress was hindered by the rise of the Khmer Rouge, who favored agricultural collectivity as an economic orientation. In the 1950s and 1960s, public, private, and hybrid industrial enterprises were formed for rice, rubber, and other agricultural products (Ear 1995, p. 12). The expansion of factories reemerged again due to foreign investment, for example from China for the garment sector after the 1994 law of investment was issued (Bargawi 2005, p. viii). Mining and extracting natural resources since 2004 has caused some ecological imbalances. The anthropocentric revolution and human-centered ambitions have started to affect the surroundings only in recent times in Cambodia.

Thus, we can say that anthropocentric views of nature are not evident in Cambodia except in the parts of the country seeking to be part of the 'modern world'. Cambodia is an agrarian-based society, which depends largely upon productive natural resources for generating food and income. More than $40 \%$ of the national GDP has been derived from the agriculture, fishery, and forestry sector in the past $10 \mathrm{yr}$, and $70 \%$ of agricultural products contribute to economic development (MOE \& UNEP 2009, p. 11)

Land is important for Cambodian people. According to a report by Cambodia's leading independent Development Policy Research Institute (CDRI) in 2001, the average agricultural land holding is ca. 1 ha per family. However, about 20 to $30 \%$ of the total 
population owns more than 1 ha per household (nearly $70 \%$ of the total agricultural lands), and 30\% of the total population owns land between 0.5 and 1.0 ha per household (nearly $20 \%$ of the total agricultural land; MOE \& UNEP 2009, p. 24). Nevertheless, during the economic crisis of 2007, many farmers sold their land in exchange for material goods and higher social status. They were no longer concerned or grateful for the land, their source of food and energy. More and more people have followed this trend; as a result, the lands are no longer available for agricultural use. Instead, they serve the interests of business investment, leaving the land abandoned and without crops.

\section{Biocentrism}

This school of thought maintains the view or belief that the rights and needs of humans are no more important than those of other living things. In other words, it is permissible to attribute intrinsic value to all individual living entities into our moral consideration. Aldo Leopold, the father of environmental ethics, expressed his idea in the mid-twentieth century in his revolutionary essay 'The Land Ethic'. He said, 'There is as yet no ethic dealing with man's relation to land and to the animals and plants which grow upon it... The extension of ethics to this third element in human environment is... an evolutionary possibility and an ecological necessity' (Leopold 1949 p. 238-239). At that time, Cambodia was about to enter the industrial revolution, 2 centuries behind the West.

In their daily lives, Buddhist followers avoid committing Karma (bad deeds), according to the 5 precepts in Buddhism: lay followers must abstain from harming living beings, stealing, sexual misconduct, lying, and becoming intoxicated. The first parameter includes the concept of biocentrism. For example, older Cambodian Buddhists would advise people, especially younger ones, not to kill ants even if they bite, for the sake of preserving precious life. Moreover, Buddhist monks must adhere to a strict code of ethics. They must abstain from practices which would involve even unintentional injury to living creatures.

Some stories are shared, such as that of the Buddha who promulgated the rule against going on a journey during the rainy season because of possible injury to worms and insects that come to the surface in wet weather. The same concern for non-violence prevents a monk from digging in the ground. Once, a monk who was a potter prior to ordination built a clay hut and set it on fire to give it a fine finish. The Buddha strongly objected to this, as so many living creatures would have been burnt in the process. However, the monks still eat meat offered to them, unlike Buddhists in some other countries.

\section{Ecocentrism}

Ecocentrism is a point of view that recognizes the ecosphere, rather than the biosphere, as being of central importance, and attempts to redress the imbalance created by anthropocentrism. Ecocentrism goes further, giving moral consideration to ecosystems including non-biological natural features such as rocks, mountains, and rivers.

One related case in Cambodia concerns illegal logging. According to Transparency International, Cambodia's track record on illegal logging has been called into question many times before. Cambodia routinely ranks among the most corrupt countries in the world. Despite this ugly truth, a group of monks in the northern part of the country is lobbying for over a dozen protected forests to go onto the global carbon market (Mahr 2011). This group of people understands the value and numerous advantages that trees bring to other beings. In 1982, the UN General Assembly's World Charter for Nature recognized that terrestrial and marine ecosystems are lifesupport systems. It also introduced ethical considerations: 'Every form of life is unique, warranting respect regardless of its worth to man, and, to accord other organisms such recognition man must be guided by a moral code of action. ... Nature shall be respected and its essential processes shall not be disrupted' (UNGA 1982, www.un.org/documents/ga/ res/37/a37r007.html).

Cambodia does have laws for preserving endangered species. Due to the presence of charismatic megafauna such as the Asian tiger and Asian elephant, $26 \%$ of the country's land was preserved for conservation compared to $16 \%$ of Thailand, according to a 1992 review (as cited in Ali 2010) by the UN's World Conservation Monitoring Center. This large area for wildlife may also have been preserved because such species require large undisturbed terrain for survival. Moreover, Cambodia has some unique ecosystems and is famous for the Tonle Sap freshwater lake, in which more than 149 species of fish have been recorded. This natural lake provides habitat for 11 globally threatened and 6 near-threatened species of vertebrates such as spot-billed pelican and grey-headed fish eagle (Ali 2010). The coun- 
try has been engaged with private foundations and conservation groups to assist in managing the environment, including the Maddox Jolie-Pitt Foundation, World Wildlife Fund, Wildlife Alliance, and some other interested partners.

\section{Cosmocentrism}

Cosmocentrism is a relationship focused on the broader cosmos, i.e. the world or the universe. This can be seen in the intricate carved reliefs surrounding Angkor Wat on all walls. 'The Churning of the Ocean of Milk' located on the East wing represents the most celebrated carving regarding a cosmocentric relationship of all beings and the universe. The legend can be summarized as follows:

In Hindu mythology, 13 precious things including the elixir of immortality were lost in the churning of the cosmic sea. Finding them again required a joint dredging operation between gods and demons. Assisting in this endeavor was the giant serpent Vasuki, who offered himself as a rope to enable twirling of a 'churning stick'. The serpent was yanked back and forth in a giant tug-of-war that lasted for a thousand years. In the bas-relief panel, the front end of the serpent is being pulled by 91 surly-looking Asuras (demons), anchored by the 21-headed demon king Ravana; on the right are 88 almond-eyed Devas (gods) pulling on the tail, anchored by monkey-god Hanuman. The central pivot, or churning stick, is a complicated piece of imagery. Vasuki has wrapped himself around Mount Mandara, represented by a tower. At one point, Mount Mandara started to sink and had to be propped up by a giant tortoise, an incarnation of Vishnu. The Sea of Milk, or the Ocean of Immortality, is represented by innumerable fishes and aquatic creatures, which are torn to shreds as they swim close to powerful air currents near the churning stick.

Directing operations at the center is the large 4armed figure of Vishnu, closely associated with Angkor Wat's builder, King Suryavarman II. The smaller figure above Vishnu is Indra, god of the sky. The actions of the gods and demons cause Vasuki to rotate the tower-mountain and churn the sea into foam, like a giant cosmic blender. This releases a seminal fluid that creates divine ambrosia, amrita, the essence of life and immortality. Many other treasures are also flung up. Born of this action are Apsaras (celestial dancers), a purely Khmer innovation. The seductive Apsaras promise a joyful existence for those who attain the ultimate incarnation; it is assumed that higher incarnations will be male in form.
According to Angkorologist Eleanor Mannikka, who has been studying the wall for over $20 \mathrm{yr}$, the bas-relief has a practical function in marking the number of days between the winter and summer solstices. Mannikka maintains, 'the 91 Asuras mark the 91 days between the winter solstice and spring equinox in March, while the 88 devas represent the 88 days to the summer solstice after the equinox period'. Further, 'this is just one of the hidden cosmological meanings coded at Angkor Wat, and that the temple is remarkably attuned to the movement of the sun and moon' (Buckley 1998, http://www.veloasia.com/ buckley/churning_milk.html).

In addition, the cultural monuments of Angkor are a long standing witness to how the Khmer people have interacted with the environment over a thousand years ago through the location of the city. The Angkor temples were built of local sandstone from the Kulen Mountains. The temples were constructed to resemble mountains or are situated on hills, symbolizing Mount Meru, the spiritual mountain at the center of the Hindu universe. Reservoirs (Baray) on the entrance sides were built as a symbol of the ocean surrounding the central mountain.

\section{CAMBODIAN CULTURE AND NATURE}

\section{Symbiosis}

The interaction between 2 different organisms living in close physical association, typically to the advantage of both, is known as symbiosis. In a symbiotic view this happens to ensure the healthy equilibrium of the nature itself. Let us consider several examples.

\section{Highland culture}

Interestingly, the indigenous or 'highland' people of northeastern Cambodia have traditionally been animistic ecosystem-based cultures whose way of life is a perfect manifestation of 'bioregionalism'. They are people from Brao, Tampuan, Bunong, and other highland groups of Ratanakiri and Mondulkiri provinces (McCann 2011). To this group of people, their relationship with the natural world is understood by spiritual terms and with respect to their subsistence livelihood. Nature does not just consist of objects for consumption or economic profit, but is growing and directed by life forces, often referred to as 'spirits'. These people practice certain rituals to ensure that any actions they take and impose on the 
environment are in accordance with nature's powerful forces. This hill-tribe society has developed an inter-relationship between people itself and the natural resources on which they depend daily. O'Brien (1999, p. 374) reported that, 'indigenous people acquired knowledge and skill through hands-on experience of living in close contact with their environment and their system of resource management has developed as a response to their needs'.

\section{Folk dances}

What is the relationship between the Cambodian people and their surroundings? The idea can be illustrated through the observation of Cambodian folk dancing. In Cambodia, folk dance mostly involves animism and expresses beliefs in the supernatural. Cambodians have traditionally lived reciprocally with nature. Therefore, folk dancing was created to mimic animal expressions or to give thanks to the Mother Earth for bearing plentiful yields throughout the whole year. Sam \& Sam (1987), specialists in Khmer traditional art, listed 19 of types of Khmer folk dances, including the Trod dance, peacock of Pursat dance, wild ox dance, candle dance, coconut shell dance, fishing dance, frog dance, harvest dance, pestle dance, Krab dance, Chhayyam dance, mouth organ dance, birth wedding dance, crossbow dance, gum lac pounding dance, sacrifice of buffalo dance, Kouy dance, magic dance, and peacock of Palin dance. In this regard, folk dance not only reflects a great culture of recreational and entertaining resources, but also best describes the great bond between the Cambodians and nature. Sam \& Sam (1987) stated that 'nature is always the strongest inspiration of all [Khmer] dances coupled with customs, traditions, and beliefs, all of which have much in common. In other words, dance is not merely an optional luxury: it is a way of life, music, song, poetry, and dance are all integral parts of Khmer life'.

Proverbs

Folk dance is not the only form of expression which reveals the relationship between the Cambodians and nature. Many Khmer proverbs draw a significant bond to nature in language creativity to convey lessons of morality to the younger Cambodian generation to instill respect for the elders. An example is illustrated by the proverb 'Ngoey skork, Aon dak

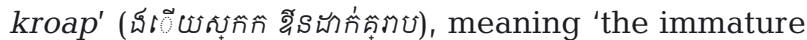

rice stalk stands erect, while the mature stalk, heavy with grain, bends over'. In Khmer, the word 'Aon' signifies respect. Another example is 'Tver srae neng

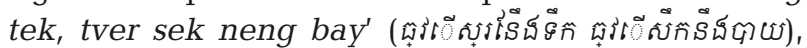
which means 'to grow rice, you need water; to fight in the battle, you need rice'. As mentioned, water and rice are the 2 crucial elements in the daily life of Cambodian people.

\section{Festivals}

The major festivals of the Cambodian calendar celebrate different stages of the agrarian cycle, which reinforce the importance of the land and water resources to the people. Bonn Om Tuk, known as the Water Festival, held on the full moon of the Buddhist month of Kadeuk (usually in November), ushers in the fishing season and the reversal of the current direction in the Tonle Sap River. Another festival, which marks the start of the plowing season, is Bonn Chroat Preah Nongkoal (The Royal Plowing Ceremony). This is the first traditional agrarian festival, featuring the connection amongst His Majesty of the Country, the king, farmers, and farming.

\section{Sculptures and tales}

Besides folk arts, traditional festivals, and proverbs, it is notable to examine the tangible cultural resource that reflects the close relationship with the environment and which has sustained the lives of the population for centuries. The Naga (Niek/Neak), a popular Buddhist image in Khmer art and architecture, expresses the close relationship between the Khmer people and the natural world. Naga is a mythical snakelike being which dwells both in the earth and water and functions as a protective guardian. Naga can be found in many Cambodian folk tales such as Preah Thong Neang Neak (also known as Kaundinya Soma).

\section{Khmer traditional calendar}

Cambodia has a different calendar system known as Chankitek (ษั่ง̧̣ติติ), which means a luni-solar calendar. The calendar is based on the movement of the moon, and calendar dates are synchronized with the solar year to keep the seasons from drifting. Since the number of days in a lunar year is shorter than the solar year, synchronization is accomplished by adding an additional month or day to a particular year. 


\section{Animal year}

Cambodians commonly identify a year of birth by using a system of 12 animals in conjunction with a 10-numeric cycle system. The 12 animals that identify the Cambodian year are named Jute (rat), Chlov (ox), Karl (tiger), Thos (rabbit), Rorng (dragon), Masagn (snake), Momee (horse), Momay (goat), Voke (monkey), Roka (rooster), Jor (dog), and Koar (pig). These Khmer names are not translation words for each of the animals but are special names created for each year. Cambodians believe that each animal possesses specific and unique qualities. Thus, people born to a particular animal year share explicit qualities associated with that animal. These qualities determine a person's characteristics including personality, fame, and fortune.

The 10-numeric cycle system is called Sak (Ñ்ñ). In Khmer, Sak means 'era' or 'counting the sequence of years', which refers to a numbering scheme from 1 to 10 used to identify a particular year. It starts with a key word-Aek, Tou, Trey, Jaktva, Pagnjak, Chor, Sabpak, Ardak, Noppak, and Somrithik, meaning 1 to 10 , respectively. Then the word ' $S a k^{\prime}$ is added to the end of each word. For example, Aeksak means the first year and Tousak means the second year. Cambodians use the Sak system to distinguish the same animal years that are in a different $12 \mathrm{yr}$ cycle. To exemplify, a $10 \mathrm{yr}$ old person is born in the same animal year as a $22 \mathrm{yr}$ old person, but they are born on a different $S a k$.

\section{Integrationism}

In Siem Reap province, the floating village of Chong Kneas houses a population of roughly 5000 people living on and from the water. The village is located on the shores of Tonle Sap Lake, approximately $15 \mathrm{~km}$ south of the city of Angkor Wat. People's lives ebb and flow with the currents of the $4000 \mathrm{~km}$ long Mekong River which feeds the Tonle Sap. The main source of income for this village comes from fishing. Nevertheless, despite the plentiful water, the standard of living in Chong Kneas is poor, with no proper sanitation and no clean water. In other words, people consume the water around them. This image is somewhat contradictory to the Cambodian belief about water. Expressed in the old saying, 'Wherever water exists, fishes exist'.

Moreover, the village does not have a permanent location. As the water recedes during the dry season, bottoming out in April, the floating houses relocate farther into the lake. When the wet season arrives, peaking in October, villagers move back inland. The population of Chong Kneas includes Cambodian, Vietnamese, and Cham (Muslims), who co-exist peacefully (Nabrdalik 2006). In a certain regard, the ability to cope with their surroundings by moving their homes twice a year illustrates the notion of integrationism in the lives of Cambodians.

\section{Apocalypse}

In 2012, when a Mayan myth of doomsday was discussed around the world, Cambodians were calm and laid back. Nonetheless, the prophecy of 'the end of the world' can be studied through the leading religion during the Angkor era.

Hinduism was of great influence in the kingdom through sea trade with India before Buddhism became the Imperial state religion. The worship of the 3 supreme gods, namely Brahma, Vishnu, and Shiva was chosen by the kings. Brahma is the creator of the world, whereas Vishnu is the protector. Shiva is the destroyer or transformer.

Shiva, one of the most popular gods, represents the concept of the apocalypse. To illustrate, after Brahma creates the world, Shiva is responsible for changing it in the form of death and destruction. He positively destroys the ego, the false identification, and instigates shedding of old habits and attachments. It is believed that all that has a beginning by necessity must have an end. Hence, in destruction, truly nothing is destroyed except the illusion of individuality. The power of destruction associated with Lord Shiva has great purifying power and opens the path for a new creation of the universe. Upholding such beliefs, Angkorians were therefore thought to believe in the power of destruction and war; as a result, they expanded their territory and occupied almost the entire peninsula of Indochina.

Upon the territorial expansion, the 'blind' worship of this 'power of war and destruction' eventually led the Angkorians to their own demise, failing to live in a proper balance with their environment, like what their god, Shiva, represents. The demise of the Angkorian era is a story of how negligence and ignoring environmental depletion brought about the end of a glorious empire.

In the book Universalism and ethical values for the environment, Rai et al. (2010, p. 11) stated that the apocalyptic view emphasizes 'the dire result of ignoring a responsible and urgent approach to tackling environmental damage and depletion'. Furthermore, they explained the elements of ignorance by referring 
to human greed (sin), lack of preparedness (sloth), waste (gluttony), over-production and accumulation of unnecessary materials (lust), and indifference (pride).

Upholding the Hindu spirit with their achievements, the ancient Angkorians had built a complex network of water management systems (corresponding to their cosmology) including channels, moats, embankments, and reservoirs (Baray) to collect and store water from the summer monsoons for rice paddy use in the case of drought. Nevertheless, with such prosperity, the root cause of the fall of this ancient civilization can be attributed to a gradual degradation in forest, water, and soil resources to meet the needs of temple building and an increasing population, over 2 million Khmer people (Hong 2007). In addition to many temple construction projects, massive irrigation projects distorted the landscape drastically to accommodate sustaining agricultural and infrastructure systems. The wood, stone, and metal that were collected, processed, or manufactured to build these structures were obtained from local quarries and jungles. The tremendous use led to the depletion of timber from local forests and farmland that was used to construct houses, temples, and cooking utensils. This rapid transformation of the landscape illustrates the close relationship between human growth and the raw materials in their environment.

\section{Management}

Do humans manage nature? Or does nature manage humans? Between the 2 actors, which is greater and more powerful? Most Cambodians consider that nature manages humans. However, it is often said that humans are clever beings that can manage natural resources, allocating some for present consumption and retaining a natural heritage for future generations. To uphold their quality of life, humans make use of agriculture, mining, fisheries, and forestry. Certainly, people and their livelihoods rely dramatically on the health and productivity of the landscape, and our actions as stewards of the land play a critical role in maintaining health and productivity.

Agriculture and food are even more fundamental to life. There are many traditions, for example, from the great lake Tonle Sap, Cambodians can harvest abundant fresh fish all year long. Nature is a source of generally abundant food, and the excess fish is preserved by making Prohok (salted fish that can be left for several years) and dried fish. Rice is widely grown, as discussed elsewhere. All agricultural resources need to be managed, and traditions have promoted this.

Nevertheless, have people effectively managed the resources? The answer is probably no. This view may be pessimistic, but it is supported by the number of times major natural disasters have hit different corners of the world. This raises the question of how much trauma have people experienced due to poor natural management of themselves? Cambodia experienced a terrible flood in late 2011. Although less severe than in Thailand, the flood caused 1.2 million people to be affected out of an estimated population of 14 million. Fuller (2011) described the very poor managerial disaster relief efforts from the Cambodian government compared to Thailand: 'In Thailand, the government has used helicopters, military vehicles and an array of equipment to reach and assist flood victims, but in Cambodia the work of providing basic necessities has been largely left to private organizations'.

A recent concern in Cambodia is mining. From 2004 to 2006, the Ministry of Industry, Mines, and Energy (MIME) had granted a total of 8 mineral exploration licenses to local and foreign companies, for projects to explore metallic minerals, including 3 for iron ore, 2 for gold, 2 for bauxite, and 1 for coal. Furthermore, since 2005, MIME had granted mining licenses to 11 companies; 5 of the licenses were for gemstone (zircon) projects, 5 were for limestone projects, and 1 was for a granite project (Wu 2006).

Ethically, we can ask how much Cambodia is prepared for the effects of resource extraction? I doubt that Cambodia will be able to manage the imbalance of its surroundings over the long term, and more attention needs to be paid to sustainable environmental management.

\section{Apathy}

Apathy means showing or feeling no interest, enthusiasm, or concern. The trait has become common for people in the 21st century for the sake of business advantages. Not reacting to deforestation, despite its tremendous harmful ecological side effects, is a form of apathy. The forest, which was reported to cover 13.2 million hectares and accounted for approximately $73 \%$ of Cambodia's total land area in 1969, was reduced by 2 million hectares in 1993 due to deforestation (Savet 1999). The newest figure estimated by UNDP shows that forest cover in the country has dropped to $57 \%$, facing constant threat from logging, fuelwood dependency, lack of alternative 
energy sources, clearance for agriculture, weak forest sector governance, and economic and social land concessions (Ker 2011).

Another format of apathy is urban immigration, which is increasing, leading to pollution problems. Many people have moved to the capital city, Phnom Penh, seeking the possibility of employment and better educational opportunities. As more people have moved in, Phnom Penh has become densely populated ( $>2$ million inhabitants in 2012), with increased traffic jams and heavy air pollution from vehicle exhausts. As urbanization is increasing, more infrastructure is needed. As a result, people are increasingly surrounded by human-made environments, such as buildings, and are cut off from the natural environment. Natural resources such as forests are put under increasing pressure to accommodate the needs of industries and consumers.

\section{Animism}

Animistic beliefs in a supernatural power that organizes and animates the material universe is deep-rooted in the Cambodian mindset. A small spirit house found in the front yard of almost every household expresses the idea of animism. The god living inside is called 'Preah Phumi' (the earth god) who will protect the house. A similar type of animistic belief is represented by the offering of sweets and candies to young little spirits known as 'Ma-rinh Kong Veal'. Most Cambodians believe that these little spirits will take good care of the family and prevent bad luck in the future.

A deeper animistic belief is that of the Phnong, an ethnic group populating the eastern part in Mondulkiri province. They live off the land and still practice shifting (slash and burn) cultivation. An example of animism is a 'magic pole' that can be found in almost every household as well as in the paddy fields. These poles are decorated with bamboo fibers that have been dyed with red paint (formerly with blood), a small slit drum to call the spirits, a small elephant head which symbolizes strength and can thus protect the people and their possessions, and a small basket, similar to those used for offerings. The items found on magic poles in houses and fields are normally more or less the same, whereas at wells, they often include small water buffaloes instead of elephant heads. Sometimes the poles have additional items, e.g. a small house. The Phnong people have intense faith that the pole will invite many spirits to protect people, to ensure good luck and a good harvest, and especially to ward off the evil spirits. Furthermore, the Phnong people still practice animal sacrifices to appease angry spirits or to thank benevolent spirits for helping them obtain a good harvest or cure illnesses (Neuenhofer no date).

\section{CONCLUSION}

It is undeniable that Cambodians are strongly attached to nature. With its favorable geographical landscape, abundant natural resources, and its rich cultural history, Cambodia has been living harmoniously with its surroundings. Rarely has Cambodia suffered from major natural disasters except droughts and flooding. Additionally, religion plays a very strong and influential role in the lives of Cambodians. Although the national religion of the country is Buddhism, it is more comparable to a 'hybrid' of Hinduism and the main religion itself. Nevertheless, not many Khmer realize that some rituals stem from Hinduism, because they are more familiar with Buddhism and many have lost their awareness of the roles of Hinduism over history. Moreover, the pillar of the country, which also contributes to natural prosperity, is culture. Folk dancing, proverbs, festivals, and architectural style illustrate how the Khmer have maintained a relationship with their lifelong partner, nature.

Unfortunately, Cambodia is becoming globalized, giving rise to increased pollution and urbanization, as well as several major problems such as deforestation. Unlike developed countries, Cambodia has not prepared for the upcoming effects of modern development. Many ethical issues are raised with this development. This paper should enable people, including Cambodians, to understand the core values of the reciprocity of living with nature and reconsider the ways humans treat nature in the present state. We have a long history of ethics of living closely with nature, and many aspects of cultural history promote that close relationship.

Acknowledgements. This paper is part of the Ethical World Views of Nature project coordinated by Jasdev Rai and Darryl Macer, and the author appreciates their help.

\section{LITERATURE CITED}

Ali HS (2010) Developing Cambodia's mining sector: an environmental perspective. UNDP, Phnom Penh

Ang C (1988) The place of animism within popular Buddhism in Cambodia: the example of the monastery. Asian Folklore Studies. Available at http://aefek.free.fr/iso_ album/angchoulean1.pdf (accessed 4 April 2012) 
Bargawi O (2005) Cambodia's garment industry: origin and future prospects. Overseas Development Institute, London

Buckley M (1998) The churning of the ocean of milk. In: Vietnam, Cambodia and Laos Handbook, 2nd edn. Avalon Travel Publishing, New York, NY. This excerpt is available at www.veloasia.com/library/buckley/churning milk.html (accessed 9 April 2012)

Bureau of East Asian and Pacific Affairs (2011) Background note: Cambodia. Available at www.state.gov/r/pa/ei/bgn/ 2732.htm (accessed 9 April 2012)

Ear S (1995) Cambodia's economic development in historical perspective: a contribution to the study of Cambodia's economy. University of California, Berkeley, CA

McCann G (2011) Animism in Cambodia: bioregional living in practice. The Trumpeter 27:8-22

Fuller T (2011) Relief is slow to reach Cambodia flood victims. Available at www.nytimes.com/2011/11/03/world/ asia/floods-in-cambodia-affect-more-than-a-million.html (accessed 11 April 2012)

Hong U (2007) The Angkor empire, environment and conflict. ICE case studies. Available at http://www1. american.edu/ted/ice/ankorwat.htm (accessed 21 September 2013)

Leopold A (1949) A Sand County almanac: with essays on conservation from Round River. Oxford University Press, New York, NY

Mahr K (2011) In Cambodia, monks take on the carbon market. Available at http://ecocentric.blogs.time.com/2011/ 05/09/in-cambodia-monks-take-on-the-carbon-market/ \#ixzz1r89DBl1O (accessed 5 April 2012)

Nabrdalik M (2006) The floating villagers of Cambodia.

Editorial responsibility: Darryl Macer,

Bangkok, Thailand
Available at www.viiphoto.com/detailStory.php?news_ id=986 (accessed 9 April 2012)

MOE (Ministry of Environment), UNEP (United Nations Environment Program) (2009) Cambodia environment outlook. MOE, Phnom Penh

Ker M (2011) UNDP-GEF joint project helps Cambodia save forests. Available at www.undp.org/content/undp/en/ home/presscenter/pressreleases/2011/05/31/undp-gefjoint-project-helps-cambodia-save-forests.html (accessed 11 April 2012)

Neuenhofer C (no date) The animist Phnong hill tribe in Mondulkiri province, Cambodia. Available at www. pbase.com/neuenhofer/phnong_hill_tribe_in_mondulkiri (accessed 10 April 2012)

O'Brien N (1999) Environment: concepts and issues, a focus on Cambodia. Ministry of Environment (MOE), United Nations for Development Program (UNDP), Phomp Penh

Rai JS, Thorheim C, Dorjderem A, Macer D (2010) Universalism and ethical values for the environment. UNESCO, Bangkok

Sam S, Sam CM (1987) Khmer folk dance. Khmer Studies Institute, Newington, CT

Savet E (1999) Forest and land fire prevention in Cambodia. IFFN No. 20. Available at www.fire.uni-freiburg.de/iffn/ country/kh/kh_1.htm (accessed 3 April 2012)

UNGA (United Nations General Assembly) (1982) World charter for nature. Available at www.refworld.org/docid/ 3b00f22a10.html (accessed 3 April 2012)

Wu JC (2006) The mining industry in Cambodia. Minerals yearbook: Cambodia. Available at http://minerals.usgs. gov/minerals/pubs/country/2006/myb3-2006-cb.pdf (accessed 9 April 2012)

Submitted: January 2, 2013; Accepted: October 1, 2013 Proofs received from author(s): December 20, 2013 